\title{
QUEEN'S
UNIVERSITY
BELFAST
}

\section{Towards a Gender Politics of Aging}

Carney, G. (2017). Towards a Gender Politics of Aging. Journal of women \& aging, 1-17. https://doi.org/10.1080/08952841.2017.1301163

Published in:

Journal of women \& aging

Document Version:

Peer reviewed version

Queen's University Belfast - Research Portal:

Link to publication record in Queen's University Belfast Research Portal

Publisher rights

Copyright 2017, Taylor \& Francis.

This work is made available online in accordance with the publisher's policies. Please refer to any applicable terms of use of the publisher.

\section{General rights}

Copyright for the publications made accessible via the Queen's University Belfast Research Portal is retained by the author(s) and / or other copyright owners and it is a condition of accessing these publications that users recognise and abide by the legal requirements associated with these rights.

Take down policy

The Research Portal is Queen's institutional repository that provides access to Queen's research output. Every effort has been made to ensure that content in the Research Portal does not infringe any person's rights, or applicable UK laws. If you discover content in the Research Portal that you believe breaches copyright or violates any law, please contact openaccess@qub.ac.uk. 
Towards a Gender Politics of Aging (Running Head: Towards a gender politics of ageing)

\title{
Gemma M. Carney, PhD*
}

*School of Social Sciences, Education and Social Work, Queen's University Belfast. 6, College Park, Queen's University Belfast, Northern Ireland. +44 2890973749.

Email address: g.carney@qub.ac.uk.

\begin{abstract}
The article proposes a Gender Politics of Aging approach to the study of aging societies. The approach recognizes the feminisation of old age, ageism's roots in sexist discourse, and the need to recognise the role of politics in driving demographic debates. Drawing together arguments from feminist gerontology and political demography, the article argues that the intersection of politics and gender must be considered if appropriate responses to an older, feminised demography are to be produced. I conclude that the work of aging feminists provides a rich vein of research and praxis from which gender politics of aging approach can draw.
\end{abstract}

KEYWORDS: Aging feminists, ageism, feminism, political demography.

\section{INTRODUCTION}

In this article, I set out the case for theorising and researching demographic aging with a feminist lens. Using recent work by Dahlerup (2016), I propose a Gender Politics of Aging Approach which acknowledges the feminisation of old age, and ageism's roots in sexist discourse. The approach also recognises that mainstream research on aging is gender-blind. The article outlines a challenge for feminists to augment the status and significance of feminist inquiry, which leads the field in terms of critical and emancipatory approaches to understanding population aging (see Cruikshank, 2003; 
Calasanti, Slevin and King, 2008; Calasanti, 2016; Harper, 2016; Woodward, 2003). A self-consciously politicised approach to researching old age is necessary if we are to produce a set of institutions and policy responses which confront the reality of increasing gender inequality and feminisation of old age (Weitz and Estes, 2001; Woodward, 2003: 56). The paper concludes that the work of aging feminists provides a rich vein of research and praxis on which a gender politics of aging approach can draw.

\section{The Status of Gender and Women in Mainstream Research on Aging}

Research on aging (gerontology) has made significant progress in recent decades, particularly in quantifying how age-related diseases affect life expectancy (BörschSupan, 2013). Demographers have made numerous projections of the pace of aging in different regions of the world, which have been endorsed by major international organisations and supranational institutions (United Nations, 2015; European Commission, 2014). However, in the clamber to understand the implications of population aging, researchers have neglected a number of key areas, not least the role of politics in shaping demographic outcomes, and vice versa (Teitelbaum, 2015: S87). The result is a large literature on how people age, but little insight into the role of political and policy decisions in producing population change. One major hurdle has been the increasing gap between what scientists have established without doubt, versus the persistence of myths and stereotypes of old age amongst electorates (Börsch-Supan, 2013).

Demographer, Tietelbaum (2015) argues that analysis of the political implications and drivers of demographic change has fallen between two disciplinary stools. Political science has viewed demographic change as too indirect in terms of its impact on 
elections, while demographers 'seemed sceptical that actions by states could have much impact upon demographic trends' (Teitelbaum, 2015: S88). As a result, there has been little or no serious academic work on what he calls 'political demography,' the increasingly significant field of study at the intersection of political science and demography. This field has fallen into the hands of 'pundits' and 'political advisers' who make outrageous claims of 'demographic doom' (Teitelbaum, 2015). We also see public attention focused on overly generalised assumptions such as the 'rise of the grey vote' which fuel an increasingly hostile attitude towards birth cohorts born between 1945 and 1964, often referred to as the baby boomers, in mainstream policy and public debate (Walker, 2012; Macnicol, 2015).

An important finding from research of demographers like Teitelbaum (2015) and Coleman (2015) is that 'demography is not destiny.' Major drivers of demographic change such as migration, fertility and mortality are all affected by political decisions. While gerontologists have conducted important studies on older migrants (Warnes, 2013), few have investigated the role of migration in driving demographic change (Harper, 2016; Rees, Wohland and Norman, 2013). Concurrently, evidence forthcoming from longitudinal datasets suggests that demographic aging is more open to influence from politics, economics or other shocks than is presented in public debate. Recently demographers like Harper (2016) have begun to present evidence in a way which acknowledges that gender relations can and do shape demographic trends. Harper's work is valuable because it recognises the centrality of women's fertility choices (where they exist) and female education rates in bringing down total fertility rates which in turn is a major driver of population ageing. However, her work is neither explicitly feminist, nor political as she stops short of claiming that population aging is a political issue with important gender implications. 
Developing on a parallel trajectory are feminist perspectives on aging. This article seeks to connect political demography with feminist gerontology by arguing that population aging is shaped by women's choices and oppression. Moreover, many of so called 'challenges' of population ageing are rooted in ageist societal norms, which can be resisted by feminist concepts and approaches. In this, I take up the baton from Ray (2004: 119) that feminist gerontology should, in theory, practice and policies: 'push feminist movement forward in the world and to change the negative images of aging, particularly for women.'

Central to the idea that demographic ageing is an increasingly burdensome policy challenge is the concept of the 'dependency ratio' - and the belief that the number of workers to 'dependents' is decreasing. It has been felt that below replacement fertility rates left many countries in the Global North with an effective deficit in terms of productive labour (Spijker and Macinnes, 2013). This implies that rising female labour force participation rates, also affect the dependency ratio: '...later entry to employment, and earlier exit from it, has been more than offset by the large rise in employment among mothers, so that the proportion of the entire population who are at work is similar now (48\%) to what it was 60 years ago (46\%)' (Spijker and Maclnnes, 2013: 2). Women's status and longevity is also central to the scientific imperative to challenge/cure ageing, typified by active ageing and other productive, managed approaches to ageing popularised over the past three decades (Bulow and Soderqvist, 2014; Calasanti, 2016).

Sexism and the senescence paradigm: a potent mix in supporting ageism In his seminal cultural history of old age The Journey of Life, Cole (1993) identifies how and when old age stopped being accepted as a natural part of life, and began to 
be viewed as a set of health conditions that could be managed. This philosophical and political shift of ageing and older people into the territory of 'scientific management' was not surprising given the growth in scientific responses to understanding all aspects of life in the late $19^{\text {th }}$ and throughout the $20^{\text {th }}$ century. Developmental biologist, Gilbert (2000: 318) explains:

'In 1900, 50\% of American women were dead by age 58. In 1980, 50\% of American women were dead by age 81 . Thus, the phenomena of senescence and the diseases of aging are much more common today than they were a century ago... until recently, relatively few people exhibited the more general human senescent phenotype: graying hair, sagging and wrinkling skin, joint stiffness, osteoporosis (loss of bone calcium), loss of muscle fibers (sic) and muscular strength, memory loss, eyesight deterioration, and the slowing of sexual responsiveness.'

The acceptance of senescence as an immutable aspect of the human life course from the beginning of the $20^{\text {th }}$ century has dominated our understanding of life, death and any changes in between. There are two important things to note:

1) Most gains in life expectancy have been made by women, whose life expectancy is some five years longer than men's in Europe, (Eurostat, 2015).

2) Many of the projections which governments have used to plan for their ageing populations have not been subject to analysis for gender.

This gender blindness has led to problems; as longitudinal data emerge projections turn out to have been way off the mark. For instance, in 2016, results of longitudinal research from Cambridge University revealed that the prevalence rates of dementia in those aged 65 and over has not increased to the extent expected twenty years ago (Malkki, 2016). The Cambridge study reveals a gender gap in rates of dementia; men 
are much less likely to develop the disease, particularly vascular dementia. The reduced rate of dementia (perhaps the most feared of all of the demographic time bomb prophecies) was credited with lifestyle changes of men. These lifestyle changes, primarily cessation of smoking, were part of a public health message which set out to reduce coronary heart disease. A side effect was that men were now also, more likely to avoid dementia. So, while government and policy-makers have been assuming that dementia will place major pressure on states to provide eldercare, this may not be the case. Moreover, such a gender gap raises questions about whether public health interventions should be targeted at men and women in different ways, or whether women accumulate disadvantage which leads to a greater likelihood of developing dementia at the end of life. So, it would seem that the outcome of fifteen years of careful, scientific research into human aging, is the conclusion that, like other socially constructed human experiences aging is shaped by societal norms (Morelock, Stokes and Moorman, 2017).

The assumption of senescence also permeates policy planning for ageing populations. Many policy plans, including age-friendly and active ageing strategies, (see Hamblin, 2013), begin with chronological age, and then socially construct a range of problems, opportunities and possible scenarios of dependency ratios and disability rates on that basis. When senescence is assumed and essentialist reasoning is applied at the individual level, it is harmful and discriminatory. When we assume that whole sections of the population are in decline but politically strategic, the result is ill designed policies and populist slanging matches which promote the idea of intergenerational conflict (Binstock, 2010). Moreover, when ageism and sexism intersect, the problem of population ageing quickly becomes the problem of old women, as applied to the whole continent of Europe by Pope Francis in 2015 (see Carney and Gray, 2015: 128). Over 
a decade since Woodward (2003) identified anger as the necessary ingredient for a social politics of aging, the sexism/ageism nexus has become more institutionalised, particularly since the impact of austerity in advanced democracies, which also happen to be frontrunners in terms of demographic aging. For the purposes of illustration, I will concentrate on the political participation of baby boomers, and, how this affects public perception of them as a group.

Political Participation of Baby Boomers \& how they are viewed as a group

Baby boomers have a reputation for electoral activism, which is often misconstrued. For instance, Binstock (2010) has argued that the fact that over 65s receive medicare and social security, and are known to be electorally active, has contributed to a divisive politics of age-based special interests in the United States (Binstock, 2010; Moody, 2016). In Europe we see the development of a similar politics of aging whereby the fact that boomers are more likely to vote than younger cohorts is seen as problematic. Conservative commentators have argued that the combination of accumulated property wealth and their electoral activism puts older people in a position to vote strategically in their own interests, depriving younger cohorts of resources (Willets, 2010; Howker and Malik, 2010).

Some of these views are political ramifications of institutionalised retirement; having a large number of people of similar age categorised as inactive has repercussions for the status of that group in society (Carney, 2010). These views are sometimes reinforced by a casual ageism, underpinned by the assumption of senescence. The next logical step is to assume that such a mass of, essentially unemployed people of similar age will result in bloc and strategic voting. These stereotypes can be observed in newspaper headlines such as ‘Europe’s worrying gerontocracy (Charlemagne, 2010 
at http://www.economist.com/node/15867833). Again, scientific evidence contradicts this public view; political demographers argue that any expectation that predictions of a gerontocracy will result from demographic ageing are contrary to scientific evidence from Europe. Goerres (2008: 69) demonstrated that while European senior citizens do vote in higher numbers, they tend not to vote in their own interests, or cohesively as a bloc. Since then, Binstock (2011) did find some evidence of strategic voting by seniors in the US 2010 election, but we have yet to see such voting behaviour in a European context. However, for the reasons outlined by Teitelbaum (2015) earlier, the absence of data has led to ageist punditry, allowing for the social construction of boomers in negative terms (Carney, 2010). The recent 'Brexit' debates in the UK offer evidence of this negative social construction of the boomers as greedy and selfish.

'Brexit' refers to the decision by the United Kingdom of Great Britain and Northern Ireland to leave the European Union following a referendum on June 23,2016 . In the divisive and populist public debate that followed the Brexit referendum (where majorities in England and Wales - but not Scotland or Northern Ireland - voted to leave the Social Union) 'baby boomers' were blamed for voting leave. A typical comment on twitter: 'Old people drove this. The baby boomer, the most selfish generation of them all. Your death bed legacy is the end of the UK' (Smitty @desmondfunk posted 11.02pm on 23 June, 2016). This comment was followed by many more, in a similar vein: 'As they sit in their mortgage free houses with copperfastened pensions' (Yvette Shapiro @yvetteshapiro posted 11.07pm on June 23, 2016). The blaming of the 'baby boomers' for many of the problems of inequality and insecurity that have resulted from globalisation and the de-regulation of capital markets (Ragan 2010) is not new. When commenting on the response of the UK government to the global economic crisis, leading gerontologist, Alan Walker makes 
the case that demographic ageing has been used politically, as a means to justify austerity, and to promote compliance amongst electorates affected by the global economic recession (Walker, 2012). Referring to the UK coalition government (20102015), Walker offers numerous examples of how older people, and baby boomers in particular have become fair game in public debate in an age of austerity: 'Under the headline 'We simply cannot afford to pay for our old age', The Telegraph of 15 March 2012 referred to the 'burgeoning costs of an ageing population' as 'a much bigger problem' than the structural deficit' (Walker, 2012: 813). Walker refers to this trend, led by the Conservative right, such as David Willits, author of The Pinch: how the baby boomers have stolen their children's future and why they should give it back as 'The New Ageism' - where demographic ageing as an unsustainable burden becomes a self-evident truth.

\section{Where is gender in the debate on political participation of older people?}

While the fact that age identities are gendered is recognised and documented (Sawchuk, 2009: Brown and Rohlinger, 2016), gender has been ignored in the public and academic debates about the baby boomers capacity to claim electoral favours. Yet, the issue of age and political representation is linked to deeper and wider gender inequalities in political representation. While most MPs are over 50, the majority of older people, particularly the oldest old, are female (Eurostat, 2015). These women were never a political priority, from their education as little girls, through the free labour they provided as mothers, through the years they spent working for lesser pay and now as widowed old ladies who need care (Hooyman, 2002). Fiscal sustainability is never measured in terms of the free care provided by women. The opportunity cost of caring for children or relatives is not taken into account when assessing whether someone qualifies for a 'contributory pension'. By the time women reach the stage 
whereby they need eldercare, their accumulated disadvantage is seen as a problem of old age - it is rarely linked to the gendered institutions that have shaped their life trajectories (Rich, 1977). Feminists working in gerontology have argued, since the 1970s, that gender and aging intersect in many ways (Arber and Ginn, 1991; Garner, 1999; Ray, 1999). It is only now, that the numbers of older women has reached a critical mass, and that feminists have accumulated lived experience of aging, that we have enough situated knowledge of aging in patriarchal societies raises specific issues and controversies.

Why we need aging feminists to counter the ageism/sexism nexus

The most powerful work in feminist gerontology is offered by writers who express lived experience of ageism in feminist terms. Friedan's (1993) Fountain of Age, Segal's (2013) Out of Time, Greer's (1992) The Change, and de Beauvoir's (1971) Old Age are all examples of feminists, connecting their occupation of an aging body and the discrimination they experience as 'invisible' older women (King, 2013) to the intersection of ageism and sexism in basic societal norms and political institutions. Gullette $(1999 ; 2008 ; 2013)$ has made a career of pugnacious and acute critique of the seven ages of womanhood, eventually recognising herself as 'an age critic' (Gullette, 2008). She has published a series of books with titles such as Safe at Last in the Middle Years (1988) Declining to Decline (1997) and, finally, Age Wise (2013) her most overtly political book. Her feminist approach sets the tone and content for Declining to Decline, as she clearly makes an important link between biology and social status, or the aging body and her declining status: "Decline" was my new name for the enemy. If decline was a "disposition," it depended on an ideology that sank nails deep into ordinary people. Fiercely supported by institutions and dollar signs, it affected unconscious habits, every sub-identity, ways of seeing bodies, explanations 
of history. It distorted visual culture. If you fought it alone, that fight warped your eyesight and sapped your energy.' (Gullette, 1997: 191). Here, Gullette is making a plea that her perceived decline is not a personal, but a political issue, an institutionalised form of bigotry that shapes how money is made (and lost), who is in power, (or not) and who is valued by culture (or not). She calls, albeit indirectly, for a gender politics of aging: 'Like gender and racial studies, age studies have a mission, but despite AARP's millions of members, gerontology's dedicated field workers, we acutely lack an anti-decline movement' (emphasis added) (Gullette, 2008: 195). Her conclusion is a rallying cry: 'I'm not so much afraid of aging, but the new regimes of ageism ought to be terrifying us all' (Gullette, 2008: 195).

What I am suggesting here is a development on this critical feminist understanding of aging and ageism/sexism. I suggest that there is room to move the whole debate on population aging at the societal level, what is known as the political economy of aging (Estes, 1979; Walker, 1981) into the realm of gender politics. I suggest this for a number of reasons already outlined, not least that it is increasingly obvious that population aging prompts politically motivated responses by governments. Second, the pertinence of the toughest challenges of population aging (such as the rising demand for eldercare) are left as the responsibility of women (Hooyman, 2002). Finally, because recent work on feminist citizenship (Lombardo and Verloo, 2009) and the evolution of gender discourses suggest that rather than achieving the slow and steady progress in augmenting female representation and the influence of women in power, Dahlerup (2016: 5) tentatively identifies a process of stagnation or decline of women's influence; 'Defeminization?!' This progress of gender equality in political institutions must be in some way influenced by how gender intersects with other inequalities. By taking the conscious step of invoking a gender politics of aging in the 
way I propose here, this approach has the potential to move forward our understanding of intersectionality and feminist citizenship, as outlined by Lombardo and Verloo (2009: 113):

'the question of intersectionality more generally steers the debate towards more complex ways of thinking and treating gender and other inequalities (Walby, 2007), by suggesting the need to overcome a simple bipolar logic of analysis... instead of focusing on the theoretical and actual social and political problem that the various inequalities of race, gender, class and so on intersect with each other (Crenshaw, 1989).'

The work of Gullette (1997), Friedan (1993), Cruikshank (2003) and Woodward (2003) documents how sexism and ageism have affected their experience of work, family, political and cultural life in different ways throughout the life course. While sexism might be the 'the more dominant benchmark' early in life, this changes as one reaches menopause and beyond when age becomes the characteristic which is used to define group membership, capacity and worth. This temporality of experiencing intersecting forms of oppression has been documented by older feminists. Here, Margaret Simey (in Bytheway, 2005: 364) describes the impact of her $90^{\text {th }}$ birthday on others' attitudes towards her:

'The transformation was stunning. I was no longer one of them. I was an outsider. I seemed to be in a foreign country. I didn't speak the language. I didn't know the rules. I was no longer me, Margaret, very defiantly my own person. Now I was simply one of a mass of clones, a stereotype, a number, not an individual. I was old and that was all that needed to be said.' 
Citing Haraway's (1991) conception of 'situated knowledge' Woodward (2003) offers an insightful critique of the disempowering of old women through a potent mix of senescence paradigm of aging with sexism. She argues that by expecting old people's behavior (particularly old women) to be wise and dignified we are repressing any potential of anger 'that is needed to stimulate personal and social change' (Woodward, 2003: 56). She goes on to argue that '... angry women have long been labeled irrational or hysterical... anger in the old is outlawed... as "conventionally unacceptable" (Jagger, 1989 cited in Woodward, 2003: 64). This reasoning suggests that angry old women could play a vital role in shaping a more humane and culturally rich transition to an older demographic profile.

\section{How can a feminist framework be applied to aging?}

Applying a feminist framework to aging poses theoretical challenges as well as opportunities for praxis (Calasanti, Slevin and King, 2006). Dahlerup's article on the gender equality as 'closed case' is also relevant because she discusses feminist concepts and how they are applied to her analysis of the development of a hegemonic discourse that 'we-are-all-for-gender-equality' in Danish political culture (Dahlerup, 2016). She also offers a concise and insightful definition of the concept of 'Feminism': 'The classic definition of Feminism as an 'ism,' covering all the different subtypes, is that Feminism is a belief system which rests on three components: 1 . Opposition to sex hierarchy (patriarchy) as a system, which permeates the whole society. 2 . The belief that women's position is socially constructed rather than predestined by God or Nature. 3. An identification with 'the group called women' (Cott, 1987; Dahlerup, 2013).' 
Dahlerup's conceptualisation of Feminism is useful when investigating the potential of ageism and sexism operating in similar manners, and, as I have argued, of affecting the same people (i.e. women) at different points on their life course. First, the view proposed in this article - that aging at the population level is not necessarily a problem, but is conceived as a problem due to endemic sexism at the societal level (Carney and Gray, 2015) is supported by the notion of anti-ageism as a belief system, rather than an evidence based, neutral, policy intervention. For critical gerontologists (myself included) anti-ageism is more than a research question, it is a belief system akin to feminist politics. Critical gerontologists do not just 'study older people,' we seek to use emancipatory frameworks which challenge ageist ideology (Hooyman, 2002).

The second element of Dahlerup's (2016) definition applies; my contention is that the position of older people (particularly older women) is socially constructed, rather than predestined by senescence (Nature) or God. This is where the 'situated knowledge' (Lombardo and Verloo, 2009: 114) of older feminists such as Greer (1992) and Friedan (1993) is especially useful as a means to challenge senescence. On her third element - identification with 'a group called women' - the ageism/sexism analogy is less successful. While there have, rightfully, been deep debates about how the diversity of women is not represented by feminism (hooks, 1981), the diversity of the older population (across class, gender, ethnicity and the inequalities between the Global South and the Global North) has not been adequately dealt with in the gerontology literature (Sawchuk, 2009).

The challenge cuts both ways - gerontology needs to consider politics of gender, but gender analysts also need to include older women as 'old age, as a political location, has been ignored' (Calasanti, Slevin and King, 2006: 14). For instance, research on the gender impact of the economic crisis (2008 onwards) refers to the need to make 
a concerted effort to agitate to include women's issues in order to avoid the rolling back of gains made during more prosperous and stable economic times (Murphy, 2015; Cullen, 2014). This literature does not mention older women, or the intersection of age and gender, reflecting the 'relative neglect of aging women in both gerontology and feminism' (Hooyman, 2002: 4). Ignoring older women, particularly older feminists would be a mistake for any of us involved in either the anti-ageism, or feminist movements.

One way to bridge this gap could be to engage with classic feminist writings but with a gerontological gaze. For instance, re-reading Rich's (1977/1987) Of Woman Born: Motherhood as Experience and Institution but with a gerontological gaze reveals a number of interesting potential lines of enquiry. Rich's description of her approach to theorising from experience as an 'odd-fangled' approach to writing - 'personal testimony mingled with research, and theory which derived from both' (Rich, 1987: 2) now typifies how use of the first person allowed women to take ownership of their lives and experiences. Feminist writing provided a platform on which women's individual experiences could be politicised, validated and collectively challenged. A similar approach is being used by aging feminists to great effect. Friedan's (1993) Fountain of Age led the way in articulating the seismic gap between the lived experience of old age, and the gerontologists' macro-level analysis of the 'demographic time-bomb.' Since then, more and more voices have been added, in a similarly 'odd-fangled' approach (Rich, 1977), notably Cruikshank's (2003) powerful exposition of lived experience in Learning to be Old.

Second, Rich links lived experience with social institution to articulate her call to action (1977: 61-2). She discusses how once a woman becomes pregnant the weight of centuries of social conditioning, norms and expectations, societal pressures and 
demands within personal relationships fall on her like a weight, making it very difficult for her to do or say anything other than what has been done before. If we conceive old age as a similarly socially constructed institution, it helps us to understand cultural norms which deny ageing; we are not willing to begin to bear that weight - the weight of centuries of senescence - where our status and value will be cumulatively devalued, year on year. So as old age approaches we experience a 'misalignment between societal age norms and personal lived experience' which requires us to either deny our chronological age, or put some distance between our 'subjective and chronological age' (Morelock et al 2017: 16).

The experience of old age is not individual, it is to enter an institution with many of the hallmarks of Rich's depiction of motherhood in a patriarchal society. In the case of old age, we are passively handing our 'power to the world outside our bodies' (Rich, 1977: 61) because we cannot find a meaningful identity which is worth having within the strictures of the institution of old age as it currently stands. In denying our own ageing, we are denying that old age is a political status as well as a physiological transition. It is experienced differently by men and women, it is intricately related to the politics of reproduction, to our relation with the economic system and to the extent to which patriarchy dominates public and family life.

\section{DISCUSSION}

The rolling back or stagnation of female political representation and influence has a major implication for the study of older women, not least, it demonstrates that women

now in their 60s and older, specifically the baby boomers may know more about producing the kind of social and political change we identify as a 'feminist movement' 
than women who grow up with all of the benefits of gender equality legislation. Dahlerup (2016) refers to the need to recognise that gender equality is not a question of steady, forward thrust, or even slow and steady gains. Feminist gerontologists argue that similar fluctuations are evidenced across the life course: 'Divorce laws, age discrimination, limited research on their health concerns, and demeaned physical appearance individually and collectively challenge older women's attempts to age with dignity' (Hooyman, 2002: 7).

While the evidence to support this viewpoint of the feminisation of old age, which is typical in feminist gerontology, it has yet to showcase the counter evidence of aging women writers and activists who find new reasons to organise collectively, write critically and challenge ageism and sexism in later life (Segal, 2014; Woodspring, 2015). In terms of political institutions, we may also find, that what was done in the past, the low tech politics of grass roots activism, community building through women's groups could offer a way forward for both gender and gerontology scholars. The capacity of some baby boomers to organise street protests and use old-fashioned grassroots community organisation to combat cutbacks in the austerity programmes in Europe lends credence to this view (Carney, 2010). Concepts such as 'solidarity' and 'community' which provided political slogans for 1960s counter culture now challenge the rhetoric of neo-liberalism (we see this in the rise in popular, youthful support for the old Left in the UK Labour Party leader, Jeremy Corbyn, for instance). This renaissance of radical old men (Corbyn) and radical old women (Greer and Friedan) should prompt us to question whether old age always implies conservative views.

Gender, Generation and Political Attitudes 
In fact, there is research evidence that old age is not always synonymous with conservative attitudes. Galligan and McKnight's (2011) analysis of support for gender friendly policies over time found older people to be more supportive of women in political office, than younger generations. They report that the oldest cohort in their analysis of the 2002 and 2007 Irish National Election Study 'the 60-75 cohort is significantly more supportive of the idea that more women will improve politics than any of the other generations' (Galligan and McKnight, 2011: 597). They explain this finding in terms of the political socialisation of baby boomers as more engaged with a lively civil rights movement in Ireland North and South in the 1960s and 1970s. In particular, boomers had the opportunity to observe women's rights activists and the consequent election of women to political office. Later generations were not part of this movement and so did not have the opportunity to witness the people power of the civil rights movement. In New Social Movement studies, baby boomers are recognised as important campaigners for social justice. In the $21^{\text {st }}$ century the 'Raging Grannies' provide important impetus for social change (Sawchuk, 2009) and in the twentieth century, Kuhn's establishment of the Gray Panthers occupied a similarly radical, leftwing stance (Garner, 1999). This links back to Woodward's (2003) argument that we should take up Greer's call to angry protest in The Whole Woman (1999). Recent tumultuous political events such as the election of Donald Trump as US President suggest that old men on the Right have used their anger to greater effect than old women on the Left. For these reasons, it is all the more important that younger feminist scholars and activists to amplify the voices of old women. Otherwise, there is a risk that the divisive politics of the early $21^{\text {st }}$ century provide fertile ground for a generation gap within Feminism. Such a gap has been cited as a problem between older and younger feminists. For example, King (2013) refers to the 'invisible older woman' within 
the feminist movement. In public debate, younger women describe feminists as 'older women talking about the 70s' (Hanson, 2013). Left wing media are beginning to argue that some of the tried and tested methods of communal living, 'anti-hierarchal and collective working' could be of use to millennials in taking on corporations and massive income inequality (Bindel, 2015). It has even been suggested that older women could spend their retirement passing on their politics of resistance to younger women. The potential for inter-generational solidarity across the feminist movement could allow younger women to learn important elements of feminist praxis such as communal living, the value or grassroots protest, and the importance of exercising suffrage in democratic systems. This final point, that the young do not vote, and the old do, is perhaps the most urgent. A gender politics of aging underpinned by inter-generational solidarity between feminists could aim to increase political participation amongst the young, rather than simply blaming the old for being too politically active (Binstock, 2010).

\section{CONCLUSION}

This article has argued that demographic aging is neither inevitable nor natural, but it is deeply gendered. Populations ageing is the result of a complex reaction to historical change, political decision-making, technological and economic developments. How societies deal with demographic aging is inherently political. The challenge for the $21^{\text {st }}$ century is to establish a new set of structures which can cater for current and future demographic change: 'It is politics that will determine whether the structures of public pension and education systems can adjust to changing proportions of the population in youngest and oldest 'dependent' age groups' (Teitelbaum, 2015: S90). It is increasingly apparent that populations, like Western Europe and the US, which have the highest proportion of people aged over 80 are becoming feminised. For this 
reason, there needs to be more gender-sensitive analysis of the impact of population aging on women (Serrao, 2015). This work needs to be overtly feminist in order to be progressive. As Garner $(1999 ; 12)$ has argued, we must all remember that we will be old one day. As such, a gender politics of aging (not just a politics of aging) perspective is necessary to understand the deeply gendered implications of demographic change for society and policy.

\section{ACKNOWLEDGEMENTS}

This article was completed with support from the ARK Ageing programme at QUB. Thanks are due to Yvonne Galligan, Dagmar Schiek and participants at the International Political Science Association Annual Conference in Poznan, Poland, July 2016. I am grateful to comments from an anonymous reviewer whose suggestions improved the paper.

\section{REFERENCES}

Arber, S. and Ginn, J. (1991) Gender and Later Life: A sociological analysis of resources and constraints. London: SAGE.

Arber, S. and Timonen, V. (2012). Contemporary Grandparenting: Changing family relationships in global contexts. Bristol: Policy Press.

Beck, U. (1992) The Risk Society: Towards a new modernity. London: SAGE.

Bettio, Francesca, and Alina Verashchagina. (2012). Long-Term Care for the Elderly: Provisions and Providers in 33 Social Countries. Luxembourg: Publication office of the Social Union. 
Bettio, F., A. Simonazzi, and Villa, P. (2006). "Change in Care Regimes and Female Migration: The 'care Drain'in the Mediterranean." Journal of Social Social Policy 16(3): 271.

Bindel, C. (2015) 'Why the left should revisit the good old days of the feminist collective' The Guardian, July 2015.

Binstock, R.H. (2010) ‘From compassionate ageism to intergenerational conflict?' The Gerontologist, vol 50, no 5, p 574-585.

Binstock, R. H. (2011) ‘

Blinder, S. (March, 2016) 'Briefing: Non-Social migration to the UK, family and dependents' Compass, University of Oxford Migration Observatory.

Börsch-Supan, A. (2013) 'Myths, scientific evidence and economic policy in an aging world' The Journal of the Economics of Aging, 1-2 (2013): 3-15.

Boult, M. (June 24, 2016) 'Millenials Fury Over Baby Boomers Vote for Brexit' prevail at http://www.telegraph.co.uk/news/2016/06/24/millenials-fury-over-baby-boomersvote-for-brexit/)

Brown, R. and Rohlinger, D. (2016) The effect of political generation on identity and social change: Age cohort consequences, Journal of Women \& Aging, 28:2, 96-111, DOI: $10.1080 / 08952841.2014 .950138$

Bülow, M. and Söderqvist, T. (2014) 'Successful Aging: A historical overview and critical analysis of a successful concept' Journal of Aging Studies: 31(2014): 139-149.

Bytheway, B. (2005), Ageism and Age Categorization. Journal of Social Issues, 61: 361-374. doi: 10.1111/j.1540-4560.2005.00410.x. 
Calasanti, T. (2007) ‘Bodacious Berry, Potency Wood and the Aging Monster: Gender and Age Relations in Anti-Aging Ads' Social Forces. 86: 1; 335-355.

Calasanti, T. (2010) "Gender and Applied Research on Aging." The

Gerontologist, (50 ${ }^{\text {th }}$ anniversary issue) 50(6): 1-15. doi: 10.1093/geront/gnq085

Calasanti, T. (2016) 'Combating Ageism: How successful is successful aging?' The Gerontologist. 56(6): 1093-1101.

Calasanti, T. (2006) 'Ageism and Feminism: From 'et cetera' to center' NWSA Journal. 18(1): 13-30.

Charlemagne (2010) 'Europe's worrying gerontocracy: what happens when older voters dominate European elections' The Economist (http://www.economist.com/node/15867833 downloaded, November 1, 2016).

Carney, G. (2010) Citizenship and structured dependency: the implications of policy design for senior political power' Ageing \& Society, 30 (2010): 229-251.

Carney, G. and Gray, M. (2015) 'Unmasking the elderly mystique: why it is time to make the personal political in aging research' Journal of Aging Studies, 35 (2015): 123-134.

Coleman, P. (2015) 'Population aging - the long view,' Population Studies, 69: sup1, S87-S95.

Cole, T. (1992) The Journey of Life: A Cultural History of Aging in America. Cambridge: Cambridge University Press. 
Cullen, P. (2014) 'Feminist NGO's and the Social Union: Contracting Opportunities and Strategic Response' Social Movement Studies: Journal of Social, Cultural and Political Protest, DOI: 10.1080/14742837.2014.965674.

Cruikshank, M. (2003) Learning to be Old: Gender, culture and aging. Lanham: Rowman and Littlefield.

Dahlerup, D. (2016) Gender discourses in an imagined gender equal society- results from a survey of the members of the Danish parliament 2015 presented at the Social Consortium for Political Research, Pisa, Italy, April, 2016. (cited with permission). De Beauvoir, S. (1972). Old Age. London: Penguin.

Estes, C. 1979. The Aging Enterprise : A Critical Examination of Social Policies and Services for the

Aged. Jossey-Bass, San Francisco, California.

Estes, C. 2001. Social Policy and Aging : A Critical Perspective. Sage, Thousand Oaks,

California.

Estes, C., Biggs, S. and Phillipson, C. (eds) 2003. Social Theory, Social Policy and Aging :

A Critical Introduction. Open University Press, Maidenhead, UK.

European Commission (2014) 'Population Aging in Europe: facts, implications and policies' Brussels: Social Commission at (http://www.net4society.eu/_media/Population_Aging_in_Europe.pdf).

Eurostat, (2015) 'Mortality and Life Expectancy Statistics' at http://ec.europa.eu/eurostat/statistics$\underline{\text { explained/index.php/Mortality and life expectancy statistics }}$ 
Fealy, G., McNamara, M., Treacy, M. and Lyons, I. (2012) 'Constructing aging and age identities: a case study of news article discourses' Aging and Society, 32 (1): 85102.

Friedan, B. (1993) The Fountain of Age. New York, NY: Simon \& Schuster.

Freixas, A., Luque, B. and Reina, A. (2012) 'Critical feminist gerontology: In the back room of research' Journal of Women and Aging, 21:1, 44-58.

Galligan, Y. and McKnight, K. (2011) 'Attitudes towards women in politics: Gender, generation and party identification in Ireland' Parliamentary Affairs, 64(4): 585-611.

Garner, D. J. (1999) 'Feminism and Feminist Gerontology' Journal of Women and Aging, 11: 2-3, 3-12.

Gilbert, F. (2000) 'Aging: the biology of senescence' in Developmental Biology. $6^{\text {th }}$ edition. Sunderland: Sinaur Assocs.

Goerres, A. (2008) The political participation of older people in Europe, London: Palgrave Macmillan

Gullette, M. (2007) 'What exactly has age got to do with it? My life in critical age studies' Journal of Aging Studies, 22: 189-195.

Gullette, M. (2013) Agewise: Fighting the New Ageism in America. Chicago, IL: The University of Chicago Press.

Gullette, M. (2004) Aged by Culture. Chicago, IL: University of Chicago Press.

Gullette, M. (1988) Safe at Last in the Middle Years. Berkley: University of California Press. 
Gullette, M. (1997) Declining to Decline: Cultural Combat and the Politics of the Midlife. Charlottesville, VA: University of Virginia.

Greer, G. (1992) The Change: Women, Aging and the Menopause. New York: Alfred Knopf.

Hagestad, G. and Uhlenberg, P. (2005) 'The Social Separation of Old and Young: A root of ageism' Journal of Social Issues, 61(2): 343-360.

Hamblin, K. (2013) Active Aging in the European Union: Policy convergence and divergence. Basingstoke: Palgrave Macmillan.

Hanson, A. (2013) 'What's wrong with older women talking about the 70s?' The Guardian, 19 August 2013.

Haraway, D. (1984) 'Primatology is Politics by Other Means' PSA: Proceedings of the Biennial Meeting of the Philosophy of Science Association. (1984): 489-524.

Harper, S. (2006) 'Addressing the implications of global aging' Journal of Population Research, 23 (2): 205-223.

Harper, S. (2016) How population change will transform our world. Oxford: OUP.

hooks, B. (1981) Ain't I a woman? Black women and feminism Boston, MA: South End Press.

Hooyman, N., Browne, C., Ray, R. and Richardson, V., (2002) 'Feminist gerontology and the life course' Gerontology and Geriatrics Education. 22: 4, 3-26, DOI: 10.1300/J021v22n04 02

Howker, E. and Malik, S. (2010) Jilted generation: How Britain has bankrupted its youth, London: Icon Books. 
King, J. (2013) Discourses of Aging in Fiction and Feminism: The invisible woman. Basingstoke: Palgrave Macmillan.

Laws, G. (1995) 'Understanding ageism: lessons from feminism and postmodernism' The Gerontologist, 35, 1, 112-118.

Lombardo, E. and Verloo, M. (2009) 'Contentious citizenship: feminist debates and practices and Social challenges' Feminist Review, 92, 108-128.

MacDonald, P. (2008) 'Very Low Fertility: Consequences, causes and policy approaches' The Japanese Journal of Population, Vol.6, No.1.

Macnicol, J. (2015) Neo-liberalising old age. Cambridge: Cambridge University Press.

Malkki, H. (2016) 'Declining dementia incidence in the UK' Nature Reviews Neurology, 12, 314, doi:10.1038/nrneurol.2016.67.

Merritt, G. (2015) 'The Refugee Crisis: Europe needs more migrants, not fewer' Europe's World at http://europesworld.org/2015/10/26/the-refugee-crisis-europeneeds-more-migrants-not-fewer/\#.V3EFEPkrLrc

Morelock, J., Stokes, J. and Moorman, S. (2017) 'Rewriting ageing to overcome misaligned age and gender norms in later life' Journal of Aging Studies. 40 (2017): 1622.

Murphy, M. P. (2015) 'Gendering the narrative of the Irish crisis' Irish Political Studies, $30: 2,220-237$.

Ray, R. (2004) 'Towards the croning of feminist gerontology' Journal of Aging Studies. 18 (2004): 109-121. 
Ray, R. and Fine, M. (1999) 'Researching to transgress: the need for critical feminism in gerontology' Journal of Women and Aging, 11: 2-3 pp. 171-184.

Rich, A. (1977/1987) Of Woman Born: Motherhood as experience and institution. NY: Bantam Books.

Rees, P., Wohland and Norman (2013) 'The demographic drivers of future ethnic group populations for UK local areas 2001-2051' The Geographical Journal, Vol. 179, No. 1, March 2013, pp. 44-60, doi: 10.1111/j.1475-4959.2012.00471.x Sawchuk, D. (2009) 'The Raging Grannies: Defying Stereotypes and Embarrassing Aging through Activism' Journal of Women and Aging, 21: 3, 171-185.

Segal, L. (2013) Out of Time: The Pleasures and Perils of Aging. London: Verso.

Serrao, S. (2015) 'Population aging and its gender dimensions: the direct and indirect impacts on women (A synthesis of literature with evidence from the Asia-Pacific region) available at (https://hr.un.org/sites/hr.un.org/files/Population\%20aging\%20and\%20its\%20gender \%20dimensions 0.pdf).

Ragan R (2010) Fault Lines: How Hidden Fractures Still Threaten the World Economy.Princeton: Princeton University Press.

Spijker, and Maclnnes, J. (2013) 'Population aging - the time bomb that isn't' British Medical Journal, 347:f 6598 doi: 10.1136/bmj.f6598 (Published 12 November 2013).

Sonntag, S. (1972, September 23) 'The Double Standard of Aging' Saturday Review of the Society, 29-32.

Teitelbaum, M. (2015) 'Political demography: Powerful trends under-attended by demographic science' Population Studies, 69: sup1, S87-S95. 
Timonen, V., Convery, J. and Cahill, S. 2006. "Care Revolutions in the Making? A Comparison of Cash-for-Care Programmes in Four Social Countries." Aging and Society 26(03): 455-74.

United Nations (2015) World Fertility Patterns at http://www.un.org/en/development/desa/population/publications/pdf/fertility/worldfertility-patterns-2015.pdf

Walker, A. (2012) 'The New Ageism' Political Quarterly, Vol. 83, No. 4, OctoberDecember 2012 DOI: 10.1111.

Warnes, T. (2013) 'Migration and Age' In Dannefer, D. and Phillipson, C. (eds.) The SAGE Handbook of Social Gerontology, London: SAGE.

Weiner, J. and Tilley, J. (2002) 'Population aging in the United States of America: implications for public programmes' International Journal of Epidemiology 2002 (31):776-781.

Weitz, T. and Estes, C. (2001) 'Adding Aging and Gender to the Women's Health Agenda' Journal of Women and Aging, 13: 2, 3-20.

Willets, D. (2010) The Pinch: How the baby-boomers took their children's future and how they can give it back, London: Atlantic Books.

Woodspring, N. (2015) Baby Boomers: Time and aging bodies. Bristol: Policy Press.

Woodward, K. (2003) 'Against wisdom: the social politics of anger and aging' Journal of Aging Studies. 17: 55-67.

World Health Organisation (2014) 'World Health Statistics, 2014' (at http://www.who.int/mediacentre/news/releases/2014/world-health-statistics2014/en/ 
